\title{
POTENCJAŁ ŹRÓDŁOWY MATERIALÓW UKRAIŃSKIEGO CZASOPISMA PRAWOSŁAWNEGO RELIGIJNO-NAUKOWY WISTNYK (ALEKSANDRÓW KUJAWSKI-SZCZYPIORNO) W LATACH 1921-1923
}

\section{Streszczenie}

Tematem artykułu jest analiza zawartości pierwszego na świecie prawosławnego czasopisma w języku ukraińskim - „Relihijno-Naukowego Wisnyka”, który było wydawane staraniem Bractwa św. Pokrowy 6. Siczowej Dywizji Strzeleckiej Armii URL, internowanej początkowo w obozie w Aleksandrowie Kujawskim, a następnie w Szczypiornie (1921-1923). Tematyka publikowanych artykułów była szeroka: od religijno-filozoficznych do historycznych. Czasopismo posiadało stałą rubrykę pod nazwą „Kronika”, w której publikowano cenne informacje o życiu kościelnym nie tylko na terytorium Ukrainy, ale i w całym świecie chrześcijańskim. Fenomen czasopisma polegał na tolerancji wszystkich religii i wierzeń, co nie było przyjęte w innych ówczesnych chrześcijańskich wydawnictwach ciągłych. „Relihijno-Naukowy Wisnyk” potrafił pozyskać do współpracy wielu wykładowców, uczonych i publicystów z różnych krajów Europy, przez co nabył znaczenia międzynarodowego.

Słowa kluczowe: Relihijno-Naukowy Wisnyk; obóz; gazeta prawosławna; Armia URL; internowanie; Szczypiorno

* Julia Golubnicha-Slenchak - absolwentka Uniwersytetu Borisa Grinchenko w Kijowie; e-mail: jgolubnycha@gmail.com

https://orcid.org/0000-0001-6591-4493 
Kwitnie dusza w niebiańskim przedsionku Prowadzi Ręka za marzenia przezroczyste.

Nie żarza smutki i udręki serca, Strapienia żal.

Do światyni, chodźcie do światyni, życia okrutne męki Pan zbierze do graala świętobliwego ${ }^{1}$.

W ciężkich warunkach obozowych, w jakich znaleźli się internowani żołnierze Armii Ukraińskiej Republiki Ludowej (URL) pod koniec 1920 roku, największym niebezpieczeństwem nie był brak odpowiedniego wyżywienia, ubrania czy środków higieny, ale powszechna rozpacz gnębiąca codziennie każdego internowanego. Gdyby serce było wypełnione wiarą w przyszłość, myślą, że we wszechświecie istnieje oś, wokół której wszystko się obraca, to można byłoby podołać wielu przeszkodom i wytrwać w tych ciężkich warunkach. Przywrócić internowanym tę wiarę i nie dać ostatecznie wpaść w rozpacz, było najważniejszym zadaniem obozowych bractw religijnych. Zajmowali się oni organizacją obozowych cerkwi polowych, prawosławnych świąt religijnych, szerzeniem Słowa Bożego. Gdyby wydawano periodyk przeznaczony do popularyzacji wartości oraz idei chrześcijańskich, to działalność tych konfraterni byłaby o wiele bardziej skuteczna. Założenie czasopisma specjalistycznego od początku było niezwykle trudną sprawą - przede wszystkim ze względu na brak środków finansowych do jego wydawania oraz odpowiednich materiałów do druku, które byłyby ciekawe i jednocześnie aktualne.

Jednak nie zważając na trudną specyfikę obozową, brak środków finansowych oraz wszystkiego, co niezbędne, z inicjatywy kapelana w obozie internowanych w Aleksandrowie Kujawskim, proboszcza cerkwi 6. Dywizji Siczowej Strzeleckiej o. Petra Bilona powstało pierwsze prawosławne czasopismo „Religijno-Naukowy Wistnyk". Stało się ono ważnym elementem rzeczywistości obozowej internowanych żołnierzy ukraińskich w Polsce. Jego tytuł wyrażał chęć wydawców do poszerzenia odbiorców pisma o nowych czytelników i prenumeratorów. W czasopiśmie publikowano nie tylko teksty o charakterze religijno-filozoficznym, ale też rozprawy historyczne i artykuły naukowo-publicystyczne.

Historia wydawnicza „Religijno-Naukowego Wistnyka” nie była jeszcze przedmiotem badań naukowych. W kontekście badań nad okolicznościami pobytu internowanej Armii URL w Polsce o czasopiśmie wspominano w pracach O. Kolanczuka ${ }^{2}$ oraz I. Sribniaka ${ }^{3}$. Niepełna informacja o „Religijno-Naukowym

${ }^{1}$ М. Обідний, Вечірня молитва, Релігійно-Науковий Вістник, Щипіорно 1922, Квітень, № 2. c. 2 .

${ }^{2}$ О. Колянчук, Українська військова емігращія у Польщуі (1920-1939), Львів: Ін-т українознавства ім. І.Крип'якевича НАН України 2000, с. 92.

${ }^{3}$ I. Срібняк, Обеззброєна, але нескорена: Інтернована Армія УНР у таборах Польщі й Румунії (1921-1924 рр.), Київ-Філядельфія 1997, с. 77; I. Sribniak, Encyklopedia jeniectwa: Ukraiński Aleksandrów. Warszawa-Paryż: Międzynarodowy konsorcium naukowo-edukacyjny im. Luciena Febvra 2018, s. 57. 
Wistnyku" jest również obecna w informatorze J. Misyła ${ }^{4}$. Przedstawienie fragmentaryczne niektórych faktów i szczegółów wydania czasopisma jest zawarte w badaniach monograficznych O. Wiszki ${ }^{5}$ oraz N. Sydorenki ${ }^{6}$. W opracowaniach ostatnich dwóch autorów podano ogólną informację o tym czasopiśmie. Sformułowano cel i zadania jego wydawców. Podano skład kolegium redakcyjnego i niektórych jego autorów. Jednak ani O. Wiszka, ani N. Sydorenko nie mieli zadania przeprowadzenia analizy szczegółowej treści czasopisma.

Pierwszy numer czasopisma powstał wspólnym wysiłkiem członków dywizyjnych Bractw Św. Pokrowy (4. Kijowskiej i 6. Siczowej Dywizji Strzeleckich) 15 września 1921 roku (jego nakład wynosił 300 egzemplarzy). Do połączonego kolegium redakcyjnego czasopisma weszło po dwóch przedstawicieli każdej z wymienionych dywizji. 6. Siczową reprezentowali Leonid Wolochiw i P. Bilon, a 4. Kijowską W. Mychałkyn i Sołodecki. Dalej wydawaniem czasopisma zajmowało się Bractwo Św. Pokrowy 6. dywizji (4. Kijowska zrezygnowała ze współpracy ze względu na brak funduszy).

W związku z przeniesieniem żołnierzy 6. dywizji do obozu w Szczypiornie pod koniec października 1921 roku kolegium redakcyjne czasopisma było zmuszone do zawieszenia swojej działalności. W tym czasie wydawcy mogli zebrać sumę potrzebną do wznowienia wydawania i wyposażenia odpowiedniego dla drukarni pomieszczenia ${ }^{7}$.

W Szczypiornie głównym redaktorem czasopisma został P. Bilon, a jego zastępcą Jewhen Baczyński. Ten ostatni w latach 1919-1921 był generalnym sekretarzem „Ukraińsko-Szwajcarskiej Handlowej Izby” i emisariuszem URL w Genewie. W 1921 roku został zaś wybrany delegatem Ukraińskiego Autokefalicznego Kościoła Prawosławnego na kongres „Uniwersalny Sojusz dla międzynarodowego braterstwa poprzez Kościoły".

W latach 1921-1923 opublikowano 15 numerów gazety. Według O. Wiszki od drugiego numeru nakład pisma wynosił blisko 370 egzemplarzy ${ }^{8}$. Liczba ta wydaje się realna ze względu na to, że na początku 1923 roku periodyk stał się organem wydawniczym Wołyńskiej Eparchii Polskiej Kościoła Prawosławnego (z siedzibą w Krzemieńcu). Jednym $\mathrm{z}$ warunków zawarcia takiej umowy było wydawanie nie

${ }^{4}$ С. Місило, Бібліографія украӥнської преси в Польщі (1918-1939) і Західно-Українській Народній Республічі (1918-19). Едмонтон: Видавництво Канадського інституту українських студій, с. 572-573.

${ }_{5}^{5}$ О. Вішка, Преса украӥнської еміграції в Польщі (1920-1939 рр.), Львів 2002, с. 273-276; його ж. Szósta Siczowa Dywizja Strzelecka Armii Ukrainskiej Republiki Ludowej. Formowanie szlak bojowy internowanie 1920-1924, Torun 2012, s. 327-328.

${ }^{6}$ Н.М. Сидоренко, Національно-духовне самоствердження у 3 ч. Преса інтернованих українців та иивільної еміграиії (Чехія, Польщча, Румунія, Єгипет, 1919-1924). К.: Дослідницький центр історії української преси 2000, t. 2, с. 55-59.; іï ж «Задротяне життя» українських часописів на чужині (1919-1924). К.: Дослідницький центр історії української преси 2000 , c. 39.

${ }^{7}$ Релігійно-Науковий Вістник, Щипіорно 1922, Квітень, № 2, с. 1.

${ }^{8}$ О. Вішка, Преса украйнської еміграції в Польщчі (1920-1939 рр.), Львів 2002, с. 274. 
mniej niż 300 egzemplarzy ${ }^{9}$. Wydanie drugiego numeru stało się możliwe dzięki materialnemu wsparciu Genewskiego Klubu Ukraińskiego i J. Baczyńskiego ${ }^{10}$. Dalej wydatki pokrywała redakcja czasopisma głównie dzięki datkom składanym na rzecz prasowego funduszu „Religijno-Naukowego Wistnyka”.

Czasopismo rozpowszechniano $\mathrm{w}$ obozach, można go było także nabyć w ukraińskich księgarniach w Łucku, Krzemieńcu, Kowlu, Ostrogu, Dubnie i Włodzimierzu Wołyńskim ${ }^{11}$. Począwszy od drugiego numeru „Religijno-Naukowego Wistnyka" można było go prenumerować także poza granicami Polski w kilku krajach Zachodniej Europy. Według relacji P. Bilona był nawet jeden prenumerator w Kanadzie ${ }^{12}$.

Celem powstania czasopisma było podołanie duchowemu kryzysowi, jaki ogarnął część internowanych żołnierzy Armii URL i ukraińskiej emigracji politycznej. Kolegium redakcyjne było świadome, że te dwie kategorie ukraińskiego społeczeństwa żyją na obczyźnie, nie mają często minimalnych zasobów materialnych, a oprócz tego ich opuszczenie z kraju wiązało się z ciężkimi moralnym przeżyciami. Zatem potrzebowali oni duchowej opieki. Pragnąc ich wesprzeć, redakcja zamieściła w pierwszym numerze tekst wstępny, w którym przypomniano czytelnikom, że można stracić wiele, ale wiara daje człowiekowi niezłomną siłę, która powiedzie wszystkich do wspólnego celu.

I jeśli dzięki naszemu czasopismu choć jeden z czytelników zamyślił się i wsłuchał się w głos swojej wiary, w głos swojej podświadomej prawdy - nasz cel został osiągnięty ${ }^{13}$ - podkreślała redakcja.

Wydawcy zachęcali swoich czytelników do nadsyłania materiałów i dzielenia się bólem.

Wszystkim pytaniom o religię, wszystkim gałęziom naszego cerkiewnego życia - pisali - wszystkim szczerym myślom, jakie budzi wiara, wszystkimi problemami naszego narodowo-kulturowego i państwowego odrodzenia [znajdzie się] miejsce na łamach naszego czasopisma ${ }^{14}$.

Znaczącym dla rozumienia potrzeby założenia czasopisma okazał sie artykuł P. Bilona „Zbawienie Ukrainy w wierze"15. Autor podkreślał w nim, że aby stanać do walki z bolszewizmem, należy być duchowo uświadomionym człowiekiem. Stwierdza on słusznie, że bolszewicy zgasili iskrę Bożą w duszach ludzi, a zadaniem każdego walczącego z nimi jest znowu zapalić ogień wiary. Na czele tej walki powinna stać Cerkiew, który ma połączyć wszystkich Ukraińców pod hasłami odrodzenia kościoła narodowego, uczczenia świątyń oraz stworzenia niepodległego państwa ukraińskiego. W artykule tym było również wezwanie do

\footnotetext{
${ }^{9}$ Релігійно-Науковий Вістник, Щипіорно 1922, Квітень, № 2, с. 37.

${ }^{10}$ Релігійно-Науковий Вістник. Щипіорно 1922, Квітень, № 2, с. 37.

${ }^{11}$ О. Вішка, Преса украӥнської емігращії в Польщі (1920-1939 рр.). Львів. 2002. с. 274.

${ }^{12}$ П Білон, Спогади, Пітсбург 1952, t. 1, с. 100

${ }^{13}$ Релігійно-Науковий Вісник, Александрів Куявський 1921, 15 вересня, № 1, с. 1.

${ }^{14}$ Релігійно-Науковий Вісник, Александрів Куявський 1921, 15 вересня, № 1, с. 1.

15 П. Білон Спасіння України в вірі, Релігійно-Науковий Вісник, Александрів Куявський 1921, 15 вересня, № 1, с. 2-3.
} 
świadczenia pomocy w wydawaniu czasopisma, na które natychmiast odpowiedziały emigracyjne ośrodki ukraińskie w Pradze i Podiebradach oraz w Genewie.

Nowe czasopismo od razu zwróciło uwagę redaktorów innych obozowych periodyków. Informacja o „Religijno-Naukowym Wistnyku” pojawiała się przeważnie w rubryce „Bibliografia” i miała na celu zapoznać czytelników z treścią czasopisma. Gazeta „Nowe żyttia” w odróżnieniu od innych czasopism w jednym ze swoich numerów podała dość negatywną recenzję pierwszego numeru czasopisma. Jej autor O. Kostiuczenko zarzucał ciężkość odbioru tekstu, przeładowanie niejasnymi terminami oraz nieodpowiednimi językowymi zwrotami, oprócz tego według recenzenta zawierał ,dużo drukarskich, gramatycznych, fonetycznych i stylistycznych błędów"16. Ogólność tej krytyki oburzyła J. Baczyńskiego - redaktora periodyku, który wkrótce w tym samym numerze opublikował swój list w obronie czasopisma. Zwrócił się w nim do autora z prośbą o wyjaśnienie, jak pierwszy numer czasopisma, wydany w takich trudnych warunkach przez jego kolegów, mógł wywołać taką lawinę negatywnych reakcji ${ }^{17}$.

Kolejny numer „Religijno-Naukowego Wistnyka” otrzymał o wiele więcej pozytywnych opinii. Gazeta wiedeńska „Soborna Ukraina” tak oceniła nowy periodyk:

Kiedyś Ukraina z wzdzięcznością wspomni tych pionerów odrodzenia ukraińskiego religijno-narodowego, którzy obecnie bez względu na ciężkie warunki wzięli na swoje barki wielką pracę wydania czasopisma religijnego, a my z całą szczerością życzymy „Daj Boże sto lat i krzyk żurawi” ${ }^{18}$.

Redaktorzy czasopisma ze szczególnym szacunkiem traktowali wszystkie chrześcijańskie wyznania, przy tym śmiało wyrażając swoje zdanie i nie bojąc się oceniać inne doktryny religijne. Taka ich pozycja, jak zaznaczali sami wydawcy, dawała podstawy do zarzutów, że czasopismo podaje w wątpliwość „czystość stricte prawosławnej idei”. P. Bilon otrzymał nawet list od protopreswitera Armii URL o. P. Paszczewskiego, w którym kategorycznie zakazywał wydawania „Religijno-Naukowego Wistnyka" bez uprzedniego ocenzurowania przez niego ${ }^{19}$.

Jednak to w żaden sposób nie wpływało na zmianę linii informacyjnej wydania, gdyż decydującym dla czasopisma była opinia kręgu czytelników o podobnych zapatrywaniach, którzy rozumieli i podzielali poglądy redakcji. Ważnym dla „Religijno-Naukowego Wistnyka” była ocena pisma prezentowana przez wiedeńską gazetę „Soborna Ukraina”. Według tego czasopisma szacunek dla innych religii, jaki dało się zauważyć na łamach „Religijno-Naukowego Wistnyka”, był jego silną stroną, co „sprawiało przyjemne wrażenie” i „przyciągało” czytelników ${ }^{20}$.

$\mathrm{W}$ trudnym wojennym i powojennym czasie najważniejszym w ocenie redakcji „Religijno-Naukowego Wistnyka” było znalezienie tego, co łączy ludzi.

${ }^{16}$ Нове життя, Александрів Куявський 1921, 6 жовтня, № 87, с. 4.

${ }^{17}$ Нове життя, Александрів Куявський 1921, 14 листопада, № 94, с. 6.

${ }^{18}$ П. Білон, Похідна церква 6 стрілецької Січової дивізії, Брацтво св. Покрови і Видавництво «До Світла». За державність. Варшава: Український Воєнно-Історичний Інститут. 1938. № 8 , c. 168 .

${ }^{19}$ П. Білон, Спогади, t. 1, Пітсбург 1952, с. 113.

${ }^{20}$ Соборна Украӥна, Відень 1922, 6 травня, № 16. 
My jesteśmy otwarci na wszystkie chrześcijańskie wyznania, bo rozumiemy, że każdemu narodowi właściwie to czy inne religijne wyznanie wypływające z tajników jego duszy, z jego narodowych cech. Dlatego nie możemy iść ani do „wojującego" moskiewskiego prawosławia, ani drogą niektórych unickich czasopism, które dla rozszerzenia swoich idei i swego wpływu nie wahają się sięgać do świadomego i dzikiego łgania pod adresem odrodzonego Ukraińskiego Kościoła Prawosławnego zapominając jakich ojców są oni dziećmi ${ }^{21}$.

W czasopiśmie często publikowano artykuły poświęcone różnym religiom. Ich wartość poznawcza polegała na tym, że autorzy nie tylko opisywali doktrynę tych wyznań, ale też próbowali przeanalizować je w świetle chrześcijaństwa, innej religii i w pewnej mierze racjonalnie ująć. Dotyczyło to zwłaszcza artykułu J. Baczyńskiego „Scientyzm a chrześciaństwo" ${ }^{22}$. Pierwsza, stosunkowo nieduża część artykułu była poświęcona przeglądowi podstawowych dogmatów doktryny religijnej, która dość szybko zyskała wielu zwolenników w USA i Europie Zachodniej. Autor zgadzał się ze znaczną częścią postulatów doktryny, choć nie uważał jej za nową, szczególnie akcentując postulat braku materii, często spotykany w okultystycznych filozoficznych poglądach przedchrześcijańskiego Wschodu. Kamieniem węgielnym stała się idea scientystów o leczeniu wad fizycznych tylko przy pomocy duchowych, spiritualistycznych praktyk, co według autora przeciwstawiało się samej nazwie religii Christian Science.

Dalej J. Baczyński wyjaśniał, że rezygnacja z wiary w świat fizyczny, materialny jest sprzeczna z doktryną chrześcijańską i jest absolutnie nienaukowa, gdyż nauka bazuje wyłącznie na świecie materialnym. Zgadzał się on z twierdzeniem scientyzmu, że pewne słowa mają siłę leczniczą i będąc skierowane w prawidłowym kierunku, mogą uzdrowić nie tylko duszę, ale również ciało. Jednak podkreślał, że scientyzm nie jest zupełnie nową doktryną, ponieważ od dawna istnieją szkoły lecznicze, w których praktykuje się autosugestię. Następnie autor podaje w wątpliwość twierdzenie scientystów o tym, że ból i choroba jako takie nie istnieją, ponieważ są to tylko złudzenia. Jednocześnie stwierdził, że w pewnym stopniu człowiek jest twórcą swojego losu zgodnie z planem Bożym. Z tego wynika, że nie ma innego zła oprócz tego, które człowiek sam może sobie uczynić, ale to zło nie jest tożsame ze światem materialnym, jak twierdzą scientyści ${ }^{23}$.

Po zbadaniu całości informacji o poglądach ideowych scientyzmu oraz jego metodach leczenia duszy i ciała autor wyszczególnił pięć podstawowych pozytywnych i informatywnych według niego twierdzeń: 1) W przyrodzie jest siła dobra pomagająca w walce ze złem; 2) Odczucie optymizmu przeważa w każdych warunkach życiowych; 3) Zniknięcie strachu przed przyszłością nieodwracalną, rzeczywiście zwykle dość mglistą; 4) Możliwość kierowania swoimi myślami

${ }^{21}$ Релігійно-Науковий Вістник, Щипіорно 1923, Серпень-жовтень, № 13-15, с. 1.

${ }^{22}$ С. Бачинський, Сієнтизм і християнство, Релісійно-Науковий Вістник, Щипіорно 1922, Квітень № 2, с. 15-19.

${ }^{23}$ С. Бачинський, Сієнтизм і християнство, Релісійно-Науковий Вістник, Щипіорно 1922, Квітень № 2, с. 17. 
i siłą woli; 5) Wzmocnienie uczuć religijnych przez postęp duchowy ${ }^{24}$.

Czasopismo omawiało też zagadnienia przeciwstawienia katolicyzmu i protestantyzmu, publikując artykuł dr Ciabini poświęcony analizie artykułów pastora A. Segonda, wydany w najbardziej wpływowym wówczas periodyku szwajcarskich kalwinistów, tygodniku „Le Sermon Religieux”. Ze względu na to, że A. Segond był protestantem, jego argumenty krytyczne wobec tego wyznania były ważne dla duchowieństwa katolickiego ${ }^{25}$.

W numerze 6 „Religijno-Naukowego Wistnyka” ukazał dodatkowo się krótki wyciąg „Negatywna strona Reformacji” z książki Marca Saunier’a Legendy symboli $^{26}$. Postulowano w nim myśl, że choć protestantyzm był zwycięstwem nad papiestwem, to nie dał oczekiwanych rezultatów, szybko bowiem „,degenerował w suchy i zimny dogmatyzm, sprzeczny z głównymi zasadami postępu duchowego ludzkości”. Za największą jego wadę filozof uważał rezygnację protestantyzmu z piękna we wszystkich jego przejawach, co tym samym niszczyło sztukę religijną leżącą u podstaw każdej religii.

Protestanyzm niszcząc uroczystość sakralną i obrzędowość zabija każdą sztukę religijną, co przemienia istnienie ludzkie w posępny i zimny grzech śpiewając hymn śmierci.

Jednak najwięcej uwagi zostało poświęcone różnym aspektom życia Ukraińskiej Cerkwii Prawosławnej. Kilka obszernych artykułów księdza N. Abramowycza dotyczyło zagadnienia upadku wiary prawosławnej i przechodzenia jej wiernych do innych wyznań. Zwrócił uwagę na to, że wojna światowa i rewolucja następująca po niej zniszczyły życie Cerkwii Prawosławnej i pobożność narodu.

Porównując niedawny atak na wschodnie kresy Polski przez przedstawicieli byłej świętej Rusi-nosicielki Boga przekonał nas o tym. Taką ciężką zniewagę Boga, taką brudną obelgę na Ducha Świętego, jaką słyszeliśmy niedawno od ludzi ruskich - nie ma przykładów w historii wiary... - słusznie zauważył N. Abramowycz ${ }^{27}$.

Rozmyślając nad przyczynami nasilenia się kryzysowych zjawisk wśród prawosławnych wiernych, autor doszedł do wniosku, że winne temu było prawosławne duchowieństwo, które nie stanęło na wysokości zadania. Cześć księży nie zwracała należytej uwagi na liturgię, która w rozumieniu autora, była jednym z najważniejszych elementów religijno-moralnego wychowania świeckich. Utrwala ona bowiem „w pamięci i wyobraźni święte postacie i czyny, nakłania do pobożnych rozmyślań, modlitwy, skłania do samozgłębienia" ${ }^{28}$.

${ }^{24}$ Є. Бачинський, Сієнтизм і християнство, Релігійно-Науковий Вістник, Щипіорно 1922, Квітень № 2, с. 19.

25 Чабіні, Реформа протестанської «реформи», Реліzійно-Науковий Вістник, Щипіорно 1922, Листопад № 4-5, с. 22-24.

${ }^{26}$ М. Соньє, Легенди символів, Релігійно-Науковий Вістник, Щипіорно 1923, Січень, № 6, c.29-30.

${ }^{27}$ Н. Абрамович, In Ноc Signo Vinces, Релігійно-Науковий Вістник, Щипіорно 1923, Лютий-березень, № 7-8, С. 6.

${ }^{28}$ Н. Абрамович, In Hoc Signo Vinces, Релігійно-Науковий Вістник, Щипіорно 1923, Лютий-березень, № 7-8, с. 9. 
Dalej N. Abramowycz wymieniał pewne warunki, jakie muszą być spełnione dla poszerzenia religijnego wpływu na wiernych. Przede wszystkim - pięknie przybrana cerkiew, estetyczny i schludny wygląd kapłana, wyraźne czytanie „,bez okrzyków i wycia", święta liturgia odprawiana bez skracań, piękny i czysty cerkiewny śpiew. Pilnej uwagi wymagało również cerkiewne malarstwo, ponieważ malowidła także miały wielki wpływ na wiernych. Jednak zdarzały się wypadki, że w niektórych cerkwiach wisiały ikony, które były niezgodne z kanonami. Autor artykułu opisywał wizytę $w$ jednej świątyni, gdzie na ikonostasie była przedstawiona „osoba w stroju archijerejskim” z ,ogoloną, złośliwą, dziką twarzą z wykrzywionymi od złości ustami i zezem - i podpisem... św Mikołaj. Tak jego tam za Mikołaja mają" 29.

Najbardziej księdza smuciło oderwanie się Cerkwii od odwiecznych ukraińskich tradycji, które wcześniej harmonijnie łączyły się z chrześcijańskimi kanonami, co czyniło Cerkiew nieodłączną częścią życia Ukraińców. Ciągłość zwyczajów i obrzędów przodków szczególnie zaciekawiała młodzież i dzieci, od małego zaszczepiając w nich miłość do Cerkwii. Autor opowiadał jak dawniej świętowano Wielkanoc:

Odwieczny zwyczaj naszej młodzieży w Wielką Niedzielę spędzać czas na cmentarzu. Dzwonią w dzwony; bawią się w ,żuka”, „,czapki”, „słup”, ,żebro"; prowadzono taniec i śpiewano pieśni „,wesnianki”, „podolanki” [...]. Nad wszystkim tym majestatycznie wznosi się cerkiewka, matka miłująca swe dzieci.

W tym - zaznaczał autor - przejawiała się rzeczywista nasza historia, prawdziwy symbolizm oraz bliskość z Cerkwią.

Tyle lat rzetelnie przeganialiśmy młodzież z cmentarza, - narzekał on, - żeby „koło cerkwi nie wygłupiali się” [...] (tutaj: bawili się - JG.) Zapomniec to wszystko nas zmuszało wojujące moskiewskie prawosławie niszcząc nasze prawosławne starożytne modlitewniki (trebniki), księgi liturgiczne (służebniki) oraz inne książki, uznając całą naszą starożytność za herezją ludzką... ${ }^{30}$.

$\mathrm{Na}$ końcu swego wywodu duchowny porównał obrazy Ostatecznego Sądu w ukraińskiej i rosyjskiej tradycji, aby jeszcze raz podkreślić różnice światopoglądów wiernych obu Kościołów. Zwracał uwagę na odmienność w przedstawianiu grzechów. Szczególnie widoczne jest to na rosyjskiej ikonie - grzechy namalowano na ciele zielonego węża zajmującego centralne miejsce w piekle. Do nich należą zabójstwo, pijaństwo, okrucieństwo, podpalenie, grabież i rozpusta. W ukraińskim wariancie tej ikony grzechy umieszczono nad poszczególnymi grupami ludzi - za rzucanie przekleństw, za niesłuchanie rodziców, za łgarstwo, za nieszczery osąd ${ }^{31}$. Obrazy grzechów odzwierciedlały światopogląd narodu. $Z$ tego

${ }^{29}$ Н. Абрамович, In Hoc Signo Vinces, Релігійно-Науковий Вістник, Щипіорно 1923, Лютий-березень, № 7-8, с. 17.

${ }^{30}$ Н. Абрамович, In Hoc Signo Vinces, Релісійно-Науковий Вістник, Щипіорно 1923, Лютий-березень, № 7-8, с. 20-21.

${ }^{31}$ Н. Абрамович, In Hoc Signo Vinces, Релісійно-Науковий Вістник, Щипіорно 1923, Лютий-березень, № 7-8, С. 24-25. 
wynika, że dla Ukraińca prawdziwe cierpienie sprawia „walka ciała i protest wewnętrznego ja" 32 .

W następnym jego artykule ,Środki do walki z sektanctwem" ${ }^{33}$ uzasadniano myśl o potrzebie „oczyszczenia” Cerkwii od narzuconej jej form i zwyczajów oraz powrotu do prawdziwych ukraińskich tradycji cerkiewnych. N. Abramowycz rozważając z tej okazji jeden z kierunków w protestantyzmie, pisał:

Sztundyzm $-z$ jednej strony jest szukaniem Żywego Boga, porywem by odnaleźć ideał, bardziej odpowiada pragnieniom duszy ludzkiej. Z dugiej - to protest, niezadowolenie z form, w jakie wcielona jest chrześcijańska idea, pociąg do osiągnięcia samej istoty idei z pominięciem jej formy ${ }^{34}$.

Autor artykułu ze smutkiem zauważył, że sztundyzm jako zjawisko najbardziej rozpowszechniło się między prawosławnymi wiernymi. Według niego przyczyny tego stanu rzeczy leżały w historii: niezrozumienie form prawosławnej doktryny przez masy, co z kolei powodowało brak odezwu w duszy ludu, czyniąc ją ,martwym prawem"; porywu duszy do żywego zjednoczenia z Bogiem; trudny, niezrozumiały język nabożeństwa. W drugiej części swego artykułu autor wskazywał na metody walki ze sztundyzmem na ogólnym i miejscowym poziomie poprzez odnowienie Cerkwii Prawosławnej.

Przeważająca część opublikowanych materiałów była poświęcona stanowisku Ukraińskiej Cerkwii Prawosławnej na Ukrainie i walce o autokefalię. Zwłaszcza wyciągi z dokumentów o ukrainizacji liturgii, „Uchwałę przedsoborowego zjazdu przedstawicieli wiejskich prawosławnych parafii Kijowskiego okręgu, który odbył się 27-28 września 1921 r. w mieście Kijowie”. W różnym czasie czasopismo opublikowało artykuł Oleksego Kostiuczenki „Bolszewicy, Cerkiew i nasze zadania”, L. Kostiuszko „Religijno-duchowy stan chłopstwa we współczesnej Ukrainie”35, B. Bidnowa „Dbajcie o autokefalię swojego Kościoła”36, I. Kobyckiego „Kilka myśli M.Kostomarowa o reformach Kościoła” i inne. Artykuł „Walka z religią na Ukrainie" o cerkiewno-wyzwoleńczym ruchu na Ukrainie w latach 19171921 podpisany inicjałami „S.T.” bazował na materiałach bolszewickiej prasy, szczególnie gazety „Wieści” ${ }^{37}$.

Na szpaltach czasopisma drukowano odczyty J. Baczyńskiego z występów na konferencjach Ligii Religii i Kongresu Międzynarodowego Aliansu Kościołów, który odbył się w sierpniu 1922 r. w Kopenhadze, obszerny referat o organiza-

${ }^{32}$ Н. Абрамович, In Hoc Signo Vinces, Релігійно-Науковий Вістник, Щипіорно 1923, Лютий-березень, № 7-8, с. 25.

${ }^{33}$ Н. Абрамович, Засоби боротьби з сектантством, Релігійно-Науковий Вістник, Щипіорно 1923, Квітень-травень, № 9-10, с. 39-48.

${ }^{34}$ Н. Абрамович, Засоби боротьби з сектантством, Релігійно-Науковий Вістник, Щипіорно 1923, Квітень-травень, № 9-10, с. 41.

${ }^{35}$ В. Біднов, Дбайте про автокефалію своєї Церкви, Релігійно-Науковий Вістник, Щипіорно 1922, Листопад, № 4-5, с. 2-13.

${ }^{36}$ В. Біднов, Дбайте про автокефалію своєї Церкви, Релігійно-Науковий Вістник, Щипіорно 1922, Листопад, № 4-5, с. 2-13

${ }^{37}$ С.Т. Боротьба з релігією на Україні, Релігійно-Науковий Вістник, Щипіорно 1922, Квітень, № 2, с. 28-32. 
cji „Pokrowskich Zbiorów Wszechukraińskiej Prawosławnej Rady Kościelnej”38 oraz o „Soborze Moskiewskiego Żywego Kościoła” ${ }^{9}$, który został zwołany ze względu na ożywienie ruchu dążącego do autokefalii Ukraińskiej Cerkwii Prawosławnej i nasilenie zainteresowania świeckich tym procesem.

Wysoką informatywność miały artykuły o charakterze religijno-filozoficznym. W pierwszych dwóch numerach ukazały się rozważania L. Wolochiwa o procesie religijnego odrodzenia z przełomu XIX i XX wieku i jego podstawowe cechy. Według myśli autora dotyczyło ono przede wszystkim uczuć (a nie myśli), apelując do „mistycznego, osobistego, wypływającego z serca światopoglądu” każdego człowieka, skłaniając go do

przewartościowania i zamiany jednych wartości, zdobytych czysto krytyczną myślą na inne powstające jako bezpośredni wymóg naszego odczuwania, naszego mistycznego jestestwa ${ }^{40}$.

Autor wyodrębnił dwa podstawowe rysy nowoczesnego religijnego ruchu opór myśli krytycznej (podobnej albo wspólnej dla wszystkich) i uczuciowego (indywidualnego, tylko wewnętrzno-osobistego postrzegania świata) oraz symbolizm Chrystusa. Opierając się na pracy rosyjskiego filozofa W. Rozanowa Ciemne Oblicze, autor podkreślił, że przezwyciężyć w sobie Chrystusa - to zmagania każdej indywidualności, jej osobisty ból i tęsknota, gdyż ta walka pochodzi jeszcze od „poganina”, który niekiedy wyjawia się w sercach ludzi. Najsilniej ta walka przejawiała się w ludziach z dużym twórczym potencjałem. Według myśli L. Wolochiwa ludzkie złudzenie polegało na pragnieniu poznania Chrystusa, a jego trzeba odczuć sercem, bowiem „Chrystus jako indywidualne uczucie każdego z nas, uczucie, a nie ujęcie myślą"41. O obrazie Chrystusa w przeciągu wieków u różnych narodów pisał też Andrij Lebedyński, rozważając o tym, czy można dać ogólne i bliskie wszystkim określenie obrazu Jezusa ${ }^{42}$.

Okoliczność wydawania czasopisma przez grupy żołnierzy ukraińskich spowodowała pojawienie się na jego szpaltach artykułu P. Bilona „O wielkim znaczeniu miłującego Chrystusa żołnierstwa"43, w którym autor stara się wyjaśnić cel i znaczenie istnienia żołnierzy jako odrębnego stanu społecznego. Na pozór bowiem zadanie „człowieka wojny” jest sprzeczne ze wszystkimi dogmatami moralności chrześcijańskiej. Jednak taki pogląd na przeznaczenie żołnierza jest powierzchowny i jednostronny. Naśladowców Jezusa apostołowie nazywali „żołnierzami chrystusowymi”, dlatego autor miał wszelkie podstawy głosić, że „wo-

${ }^{38}$ Релігійно-Науковий Вістник, Щипіорно 1923, Квітень-травень, № 9-10, с. 27-35.

${ }_{39}^{9}$ Релігійно-Науковий Вістник, Щипіорно 1923, Червень-липень, № 11-12, с. 17-28.

40 Л. Волохів, Релігійне відродження, Релігійно-Науковий Вістник, Щипіорно 1922, Квітень, № 2, с. 9.

41 Л. Волохів, Релігійне відродження, Релігійно-Науковий Вістник, Щипіорно 1922, Квітень, № 2, с. 10 .

42 А. Лебединський, Христос, Релігійно-Науковий Вістник, Щипіорно 1923, Квітень-травень № 9-10, с. 14-18.

${ }^{43}$ П. Білон, ро високе значення христолюбивого вояцтва, Релігійно-Науковий Вістник, Щипіорно 1922, Квітень № 2, с. 12. 
jownik chrześcijański to broń w rękach Bożych dla zwalczenia kłamstwa i obrony dobra, to Siła Boża. Wojownik chrześcijański jest sakralną osobą!”.

Ofiarny czyn żołnierzy ukraińskich, którzy wyruszyli w II Wyprawę Zimową i znaleźli się w listopadzie 1921 roku w niewoli u bolszewików, zwrócił szczególną uwagę P. Bilona. Żołnierze według niego przejawili prawdziwe bohaterstwo, wielkość ducha, tyle

wspaniałego piękna, miłości ofiarnej, że nie możemy nie zachwycać się tym wszystkim, nie można nie cieszyć się, to wszystko nie może nie wzruszać duszy i nie wywoływać głębokiego szacunku wobec tego bohaterstwa $\mathrm{a}^{44}$.

Autor podkreślił, że żołnierze świadomie decydowali się na tę ofiarę i bohatersko przyjęli swoją śmierć, co było wyrazem prawdziwej miłości do swojej ojczyzny. Pod koniec artykułu P. Bilon uczcił kozaka 6. Siczowej Dywizji Strzeleckiej Szczerbakowa, który w odpowiedzi na wezwanie komisarza bolszewickiego do wszystkich wziętych w niewolę, aby dołączyli do Armii Czerwonej, odpowiedział:

Wiemy, co nas czeka i nie boimy się śmierci, ale wam służyć nie pójdziemy [...]. Walczymy za idę. Wiemy, że zwyciężymy. Wszystko to znacie dobrze.

Zabijajcie, katorżnicy, jesteśmy gotowi ${ }^{45}$.

Trzeci numer czasopisma otwierała refleksja J. Baczyńskiego „Tajemnica Służby Bożej" ${ }^{46}$ o specyfice przekładu Pisma Świętego i modlitw na język narodowy. W swoim artykule starał się przedstawić przyczyny braku wykorzystywania przez duchowieństwo przethumaczonych na język ukraiński tekstów Pisma Świętego. Na początku swojego artykułu autor zauważył, że ostatnimi czasy pojawiało się coraz więcej przekładów Biblii, modlitw i liturgii, które według niego „miały wielką poetyczną i naukową wartość" ${ }^{77}$. Jednak przeważająca część szafarzy Kościoła (szczególnie wyżsi hierarchowie) nie śpieszyła się, by wykorzystywać teksty przetłumaczone na język narodowy, zrozumiały dla wierzących. Jako pierwsi nabożeństwa w języku narodowym zaczęli odprawiać protestanci, co przyczyniło się do zintensyfikowania zmiany wyznania $\mathrm{z}$ katolicyzmu na protestantyzm. Jednak - jak zaznaczył autor - ostatnio dzieje się na odwrót - to protestanci zaczęli coraz częściej wracać do katolicyzmu. Przyczyną była rezygnacja z sakramentów i czytania kazań nie w języku łacińskim.

Według J. Baczyńskiego ojcowie Kościoła zawsze byli nosicielami Słowa Bożego, a Służba Boża i sakramenty miały przede wszystkim służyć pośrednictwu między widzialnym a niewidzialnym światem. Zadaniem Cerkwii jest - wykorzystując modlitwy - łączyć te dwa światy, żeby otrzymywać „z anielskiego świata”

44 П. Білон, ро високе значення христолюбивого вояцтва, Релігійно-Науковий Вістник, Щипіорно 1922, Квітень, № 2, с. 12.

45 П. Білон, ро високе значення христолюбивого вояцтва, Релігійно-Науковий Вістник, Щипіорно 1922, Квітень, № 2, с. 14.

${ }^{46}$ С. Бачинський,Таємниця Служби Божої, Релігійно-Науковий Вістник, Щипіорно 1922 , Червень. № 3. с. 1-8.

${ }^{47}$ С. Бачинський, Таємниця Служби Божої, Релісійно-Науковий Вістник, Щипіорно 1922, Червень № 3, с. 1. 
siłę, pomoc i łaskę Bożą. W celu ustanowienia tej więzi Bożej należy wykonywać pewne rytuały - prawidłowe połączenia śpiewów, muzyki, kolorów, zapachów i gestów, które w swoim czasie były ustanowione przez świętych ojców Kościoła, którym te zadania zostały objawione przez Boga. Dlatego - jak zaznaczał autor z aniołami można skontaktować się tylko poprzez wykorzystanie konkretnych słów i dźwięków wygłoszonych w potrzebnym diapazonie dźwiękowym ${ }^{48}$. Nie oznaczało to braku możliwości przekładu Pisma Świętego na język ukraiński, ale podkreślało potrzebę podejścia do tej niełatwej sprawy z różnych stron, prawidłowy wybór nie tylko poprawnego przekładu słów, ale też uwzględnienia dźwięczności i możliwość ich wyśpiewania.

W swojej kolejnej rozprawie „Modlitwa”49 autor starał się dać odpowiedzi na trzy ważne pytania: 1) Dlaczego się modlimy? 2) Jaki jest cel naszej modlitwy? 3) Na czym polega siła modlitwy? Autor doszedł do wniosku, że człowiek modli się, poszukując poratunku i zbawienia duszy.

Gdy człowiek już nie potrafi, nie może nic uczynić, gdy jest zdany na siebie samego, żeby nie wpaść w rozpacz i świadome przestępstwo wobec samego siebie, kieruje swoją myśl i uczucia do Istoty Najwyższej, do świata niewidzialnego, lecz łaskawego [wobec niego $]^{50}$.

Cel tej modlitwy polega na prośbie człowieka, by stać się nosicielem dobra i woli Bożej poprzez swoje czyny:

Świętość jest logicznym celem naszych modlitw, gdyż stanowi największe wysławianie (podniesienie - J.G.), dobro, do którego każda indywidualność ludzka może wznosić się na tej ziemi. Przez to pragnienie człowiek wchodzi do życia wiecznego ${ }^{51}$.

Z tego wynika - według autora - że siła modlitwy przejawia się wtedy, gdy pragnienie tego, kto modli się, nie jest sprzeczne $\mathrm{z}$ wolą Bożą.

J. Baczyński przedstawił swoją klasyfikację modlitw zależnie od potrzeb duszy modlących się: 1) Modlitwy w celu wcielenia „dobra osobistego i ziemskiego" - czyli te, które wznoszone są w celu pomyślnego rozwiązania problemu; 2) Modlitwy podczas zaistnienia trudności „moralnych oraz intelektualnych" np. autor wymienia, w jakich przypadkach wznosi się te modlitwy: by otrzymać siłę do postępu duchowego, przezwyciężyć swoje wady i błędy, wytrwać w walce z pokusą itd. 52; 3) Modlitwy w pragnieniu połączenia się z Bogiem, tzw. „medytacja mędrca".

Wydawcy pilnie śledzili wydarzenia na świecie i na bieżąco wybierali do

${ }^{48}$ С. Бачинський, Таємниця Служби Божої, Релігійно-Науковий Вістник, Щипіорно 1922, Червень, № 3, с. 3-4.

49 Є. Бачинський, Молитва, Релігійно-Науковий Вістник, Щипіорно 1922, Листопад, № 4-5, c. 25-36.

${ }^{50}$ Є. Бачинський, Молитва, Релігійно-Науковий Вістник, Щипіорно 1922, Листопад, № 4-5, c. 27.

${ }^{51}$ Є. Бачинський, Молитва, Реліzійно-Науковий Вістник, Щипіорно 1922, Листопад, № 4-5, c. 28.

${ }^{52}$ Є. Бачинський, Молитва, Релігійно-Науковий Вістник, Щипіорно 1922, Листопад, № $4-5$, c. 28. 
publikacji w czasopiśmie takie materiały, które mogłyby zwrócić uwagę czytelników. $\mathrm{W}$ ten sposób podwójny nr 7-8 mieścił fragment $\mathrm{z}$ pracy współpracowniczki czasopisma, (w przyszłości żony J. Baczyńskiego) Idy Abaz-Ali-Edwards „Chrystus w Mahometyzmie”. Powodem do pojawienia się tego artykułu była wojna Turcji w obronie niepodległości i rola bolszewików w tych wydarzeniach. Redakcja „Religijno-Naukowego Wistnyka” uważała, że „Wschód mahometański powoli budzi się do aktywnej działalności i jego siłę w pierwszej kolejności starali się wykorzystywać komuniści moskiewscy" ${ }^{53}$. Jednak redaktorzy od razu zapewnili, że bolszewików czeka rozczarowanie, bowiem ,wiara była i jest charakterystyczną cechą świata islamu, który nigdy nie zgodzi się $\mathrm{w}$ ateizmem komunistycznym i dominującym w Sowrosji (Rosji sowieckiej - J.G.) materializmem"54.

W numerze piątym czasopisma został opublikowany artykuł esperantysty szwajcarskiego dr Edmonda Privat, poświęcony analizie poglądów dr Ludwika Zamenhofa o celowości zaprowadzenia nie tylko jednego języka, ale również jednej religii ${ }^{55}$. Idea stworzenia religii ,sztucznej” przede wszystkim dotyczyła ludzi, którzy utracili wiarę albo należeli do tego lub innego wyznania zgodnie z pochodzeniem, a nie zgodnie $\mathrm{z}$ własnym odczuciem czy przekonaniami. Założyciel esperanto proponował, by stworzyć religię bazująca na ogólnoludzkich wartościach moralności i tolerancji wzajemnej, tzw. „etykę religijną" ${ }^{56}$. To także miało usunąć napięcie wynikające przy zderzeniu światopoglądów różnych wyznań. L. Zamenhof proponował $\mathrm{w}$ takich przypadkach przedstawicielom różnych wyznań przede wszystkim posługiwać się zasadami „etyki religijnej”.

Niekiedy w czasopiśmie drukowano również rozprawy historyczne dotyczące różnych wątków życia społeczno-religijnego Europy. Podejściem nowatorskim wyróżniał się artykuł J. Baczyńskiego „Bractwo Krzyża-Róży” ${ }^{57}$, w którym omawiał opublikowane materiały francuskiego naukowca-okultysty, prezesa stowarzyszenia Amitiés Spirituelles dr Sédir'a (jego prawdziwe imię było ukryte pod pseudonimem - J.G.). We wstępie do swojego artykułu autor zwracał uwagę czytelników na prawie kompletny brak badań na temat historii założenia i działalności tajnego religijno-mistycznego stowarzyszenia Różokrzyżowców, (wówczas istniejące wydania na ten temat były praktycznie niedostępne i mało zrozumiałe). „Naukowo-Religjnyj Wistnyk" również opublikował na swoich łamach historyczne rozprawki dr Ciabini, wśród których były niewielkie artykuły „Sprawa

${ }^{53}$ I. Абаз-Алі, Христос в Магометанізмі, Релігійно-Науковий Вістник, Щипіорно 1923 , Лютий-березень, № 7-8, с. 1.

${ }^{54}$ I. Абаз-Алі, Христос в Магометанізмі, Релігійно-Науковий Вістник, Щипіорно 1923, Лютий-березень, № 7-8, с. 1.

${ }_{55}$ Е. Пріва, Заменгоф про необхідність релігії, Релігійно-Науковий Вістник, Щипіорно 1922, Листопад, № 4-5, с. 14-18.

${ }_{56}$ Е. Пріва, Заменгоф про необхідність релігії, Релігійно-Науковий Вістник, Щипіорно 1922, Листопад № 4-5, с. 17.

57 Є. Бачинський, Братство Хреста-Троянди, Релігійно-Науковий Вістник, Щипіорно 1923, Квітень-травень, № 9-10, с. 2. 
kościelna w czasach Wielkiej Rewolucji Francuskiej”58 i „Kościół Ormiański” W. Bidnowa „Koronacja Bogdana Chmielnickiego i Iwana Wyhowskiego" ${ }^{60}$.

Stałą rubryką czasopisma była „Kronika” podzielona na kilka podrozdziałów. Z „Kroniki Obozowej” można było dowiedzieć się o działalności bractw obozowych (św. Pokrowy 2. Wołyńskiej i 6. Siczowej Strzeleckiej Dywizji, Pułku Konnego im. I. Mazepy, śś. Cyryla i Metodego w obozie w Kaliszu), wydawnictwa religijnego „Do światła”, cerkwi polowej 6. Siczowej Strzeleckiej Dywizji w obozie Szczypiorno. Również tutaj podano do zapoznania się i dyskusji projekt „Statutu Zarządu Duchowego Prawosławnej Ukraińskiej Emigracyjnej Eparchii w Polsce" 61 .

W „Kronice Zagranicznej” zamieszczono informacje o procesie połączenia Kościoła anglikańskiego i Cerkwii Prawosławnej, publikowano krótkie zarysy o stanowisku Rumuńskiej Cerkwii Prawosławnej i sprawozdania z prac Międzynarodowego Kongresu Eucharystycznego w Rzymie, przedstawiono przegląd życia religijnego Francji. Czasopismo chętnie podawało informację o stanowisku Ukraińskiej Cerkwii Prawosławnej za granicą: m.in. w tej rubryce opublikowano wyciąg z „Wielkiego Soboru Kościelnego Ukraińskiej Cerkwii Prawosławnej w Ameryce", który odbył się 26 marca 1922 roku. Z przyjętych na tym Soborze rezolucji można było dowiedzieć się, że Ukraińska Cerkiew Prawosławna w USA uznawała siebie za część Autokefalicznej Ukraińskiej Cerkwii Prawosławnej na Ukrainie i deklarowała, że połączy się z nią, gdy „na Ukrainie władze kościelne będą w rękach Ukraińców i gdy na to pozwolą stosunki komunikacyjne”. Pierwszoplanowym zadaniem duchowieństwa była ukrainizacja Cerkwii Prawosławnej na Ukrainie i uświadomienie narodowe narodu ukraińskiego, (najbardziej aktywnie w tym kierunku działał minister rządu URL prof. I. Ogienko wraz ze zwolennikami, za co podziękowano im na łamach czasopisma ${ }^{62}$.

W periodyku istniały również rubryki „Na Ukrainie”, „Na Moskowii” oraz „W Polsce”, w których przedstawiano wydarzenia z życia Kościołów narodowych. Rubryka „W Polsce” zawierała m.in. materiały na temat życia Eparchii Wołyńskiej, wybory nowego metropolity Cerkwii Prawosławnej w Polsce abpa Dionizego ${ }^{63}$, założenie Wyższej Szkoły Prawosławnej i ukazanie się nowych prawosławnych czasopism „Wiestnik Prawosławnoj Metropolii w Polsze"64. W numerach 9-10 znajdowała się krótka relacja z procesu sądowego byłego archimandryty Pawła Łatyszenki w sprawie zabójstwa metropolity Jurija ${ }^{65}$. Naj-

58 Чабіні, Церковна справа за часів Великої французької революції, Релігійно-Науковий Вістник, Щипіорно 1922, Квітень, № 2, с. 19-22.

59 Чабіні, Вірменська церква, Релігійно-Науковий Вістник, Щипіорно 1923, Серпень-жовтень, № 13-15, с. 26-28.

${ }^{60}$ В. Біднов, «Коронування» Богдана Хмельницького та Івана Виговського, Релігійно-Haуковий Вістник, Щипіорно 1923, Червень-липень, № 11-12, С. 28.

${ }^{61}$ Релігійно-Науковий Вістник, Щипіорно 1923, Січень, № 6, с. 36-37.

${ }^{62}$ Релігійно-Науковий Вістник, Щипіорно 1922, Листопад, № 4-5, с. 48-49.

${ }^{63}$ Релігійно-Науковий Вістник, Щипіорно 1923, Лютий-березень, № 7-8, с. 59.

${ }^{64}$ Релігійно-Науковий Вістник, Щипіорно 1923, Лютий-березень, № 7-8, с. 61.

${ }^{65}$ Релігійно-Науковий Вістник, Щипіорно 1923, Квітень-травень, № 9-10, с. 53-54. 
więcej informacji w tej rubryce opublikowano w numerach 11-12. Pisano w niej o organizacji ukraińskiego zjazdu emigracyjnego w Warszawie, założeniu Prawosławnego Wydziału Teologicznego przy Uniwersytecie Warszawskim, przygotowaniach Synodu Świętego Metropolii Prawosławnej do Soboru Kościelnego w Polsce w 1923 roku oraz opublikowano statut Mieszanego Soboru Kościelnego w Polsce (do którego składu należeli biskupi, klerycy i świeccy) ${ }^{66}$.

Rubryka „Bibliografia” zawierała recenzje i przeglądy literatury religijnej wydawanej na ziemiach ukraińskich, a także poza nimi, dzięki wysiłkom ukraińskim emigrantom. Szczególnie ciekawe były opinie W. Bidnowa na broszurę A. Barwińskiego Czy język ukraiński jest przydatny do przekładu Pisma Świętego i modlitw oraz kazań duchownych ${ }^{67}$, przegląd i ocena treści broszur I. Ogienki Jak Moskwa podporzadkowała wolny Kościót Ukrainy i W. Bidnowa Sprawa kościelna na Ukrainie ${ }^{68}$. Opublikowano w niej również wykonaną przez D. Doroszenkę recenzję książki W. Erna Życie i osoba G. Skoworody, która wyszła drukiem w wydawnictwie obozowym „Do switła" ${ }^{69}$. Tutaj też była niewielka, ale stała rubryka „Ogłoszenia”

Z okazji wielkich świąt religijnych publikowano życzenia od redakcji i materiały tematyczne. $W$ jednym $\mathrm{z}$ bożonarodzeniowych numerów umieszczono fragment pracy Giovanni Papiniego Historia Chrystusa (w przekładzie Walentyny Andrijko ${ }^{70}$. Dalej były rozmyślania Andrzeja Lebedyńskiego „Kto nas rozłączy?" natchnione świętowaniem Bożego Narodzenia w obozach, daleko od rodziny i bliskich ludzi ${ }^{71}$. W historycznej rozprawie J. Baczyńskiego „Symbolizm bożonarodzeniowej choinki" 72 opowiadał on czytelnikom o pochodzeniu tradycji stawiania i ozdabiania choinki oraz powiązanych z nią wierzeń. Marcowy numer 7-8 oprócz życzeń z okazji Wielkanocy mieścił artykuł Wiaczesława Prokopowycza z okazji rocznicy urodzin Tarasa Szewczenki „Szewczenko i my”. Autor ze smutkiem podkreślał, że jemu współczesni w ogóle nie są zaznajomieni z twórczością wielkiego poety, którego słusznie nazywają ,prorokiem naszego narodowego odrodzenia”. Swoim artykułem pragnął jeszcze raz przypomnieć internowanym i emigrantom, jak bliski i rodzimy jest Kobzar dla każdego, czego on uczy ,nas na wygnaniu, na cudzej ziemi”" ${ }^{73}$.

Ze względu na to, że „Religijno-Naukowy Wistnyk” złączył we współpracy wielu wykładowców, uczonych i publicystów z różnych europejskich krajów, od

${ }^{66}$ Релігійно-Науковий Вістник, Щипіорно 1923, Червень-липень, № 11-12, с. 44-48.

${ }^{67}$ Релігійно-Науковий Вістник, Щипіорно 1922, Квітень, № 2, с. 39-40.

${ }^{68}$ Релігійно-Науковий Вістник, Щипіорно 1922, Квітень, № 2, с. 40.

${ }^{69}$ Релігійно-Науковий Вістник, Щипіорно 1923, Квітень-травень, № 9-10, с. 57.

${ }^{70}$ Папіні Дж, Історія Христа, Релігійно-Науковий Вістник, Щипіорно 1923, Січень. № 6. c. 1-3.

${ }^{71}$ А. Лебединський, Хто нас розлучить, Релігійно-Науковий Вістник, Щипіорно 1923, Сiчень, № 6, с. 4-6.

${ }^{72}$ Є. Бачинський, Символізм Різдвяної ялинки, Релігійно-Науковий Вістник, Щипіорно 1923, Січень, № 6, с. 7-12.

${ }_{73}$ В. Прокопович, Шевченко і ми, Релігійно-Науковий Вістник, Щипіорно 1923, Лютий-березень, № 7-8, с. 26-34. 
samego początku pismo wyszło poza granice obozów internowania ukraińskich żołnierzy w Polsce i nabrało międzynarodowego rozgłosu. Warto wspomnieć, że w jego wydawanie włączyli się m.in. Walentyna Andrijko (Paryż-Francja), prof. D. Dorowycki (Podbierady-Czechosłowacja), prof. Georges Meotis (Neuchâtel-Szwajcaria), dr E. Privat (Genewa-Szwajcaria), Luisa Role (Genewa-Szwajcaria), W. Polisadiw (Lozanna-Szwajcaria), dziekan Wydziału Teologicznego Uniwersytetu Genewskiego E.Chausie, dr Ciabini (Rzym-Italia), Monschato Teling (Oberhambach-Niemcy) oraz inni.

Jeszcze jedną osobliwością czasopisma była obecność (jako dodatek) Kaznodziejskiej kartki, która ukazywała się z kolejnymi numerami „Religijno-Naukowego Wistnyka". Można go było kupować w zestawie z czasopismem, (cena kompletu z wysyłką w granicach Polski wynosiła 100 marek polskich, a kupowany osobno - 300 marek polskich).

Drugie wydanie Kaznodziejskiej kartki dodano do szóstego numeru czasopisma. Zamieszczono w nim kazania księży N. Abramowycza „Na niedzielę Syna Marnotrawnego”, P. Bilona „Na niedzielę Mięsopustu”, P. Wasylkiwskiego „W dzień Wniebowstąpienia Pana Naszego Jezusa Chrystusa”, A. Lebedyńskiego „Słowo w niedzielę Prawosławia" "74. Wszystkich egzemplarzy Kaznodziejskiej kartki nie udało się odnaleźć, ale ze względu na ilość numerów czasopisma, można szacować na mniej niż siedem numerów ${ }^{75}$.

Chociaż wydawanie pisma „Religijno-Naukowy Wistnyk” zostało przerwane jesienią 1923 r. wraz z likwidacją obozu w Szczypiornie (październikowy numer 13-15 stał się zarazem ostatnim) periodyk zostawił po sobie znaczący ideowo-światopoglądowy dorobek. Był on pierwszym na świecie ukraińskim i zarazem prawosławnym periodykiem wydawanym $\mathrm{w}$ języku ukraińskim i mającym kilkunastotysięczne grono czytelników: internowanych żołnierzy Armii URL i emigracyjnych polityków. Nie zważając na trudne warunki w jakich permanentnie przebywali jego twórcy, udało im się wydawać czasopismo o wysokim poziomie merytorycznym, $\mathrm{z}$ aktualnymi i ważnymi treściami przeznaczonego dla wiernych Ukraińskiej Cerkwii Prawosławnej. Redaktorzy czynnie działali w sprawie ukrainizacji prawosławnego Kościoła, odrodzeniu narodowych prawosławnych tradycji, przeciwdziałając $\mathrm{w}$ ten sposób szerzeniu się demoralizacji ukraińskich żołnierzy internowanych w obozach w Polsce.

Fenomen ukraińskiego religijnego, prawosławnego czasopisma polegał na jego tolerancji względem wszystkich wyznań, i podjęcia się próby przez jego wydawców zrozumienia i analizy dogmatów innych religii. Redaktorzy stali przy tym na stanowisku wolności myśli i słowa. Wydawcy publikowali artykuły swoich kolegów, nawet gdy sami nie zgadzali się z ich poglądami. Taka pozycja redakcji napotykała na silny opór i krytykę ze strony Episkopatu Cerkwii Prawosławnej, jednak nie spowodowało to zmiany przez P. Bilona i J. Baczyńskiego wyrzeczenia się swoich zasad. Można ich uważać za pionierów popularyzacji religijno-narodowego odrodzenia Ukraińskiej Cerkwii Prawosławnej za pomocą specjalistycznego pisma.

${ }^{74}$ Проповідницький листок, Щипіорно 1923, Січень, № 2, с. 12.

${ }^{75}$ О. Вішка, Преса украӥнської еміграції в Польщі (1920-1939 рр.), Львів 2002, с. 274. 


\section{BIBLIOGRAFIA}

\section{Opracowania}

Bilon Petro, Spohady, t. 1, Pitsburh 1952.

Kolianchuk Oleksandr, Ukrainska viiskova emihratsiia u Polshchi (1920-1939), Lviv 2000. Misylo Eugeniusz, Bibliohrafia ukrainskoi presy v Polshchi (1918-1939) i Zakhidno-Ukrainskii Narodnii Respublitsi (1918-19), Edmon 1991.

Sribniak Irop, Encyklopedia jeniectwa: Ukraiński Aleksandrów, Warszawa-Paryż 2018.

Sribniak Irop Obezzbroiena, ale neskorena: Internovana Armiia UNR u taborakh Polshchi y Rumunii (1921-1924 rr.), Kyiv-Filiadelfiia 1997.

Sydorenko N., "Zadrotiane zhyttia» ukrainskykh chasopysiv na chuzhyni (1919-1924), K.: Doslidnytskyi tsentr istorii ukrainskoi presy. 2000.

Sydorenko N., Natsionalno-dukhovne samostverdzhennia u 3 ch. Presa internovanykh ukraintsiv ta tsyvilnoi emihratsii (Chekhiia, Polshcha, Rumuniia, Yehypet, 19191924). K.: Doslidnytskyi tsentr istorii ukrainskoi presy. 2000, t. 2.

Vishka O., Presa ukrainskoi emihratsii v Polshchi (1920-1939 rr.), Lviv2002.

Vishka O., Szósta Siczowa Dywizja Strzelecka Armii Ukraińskiej Republiki Ludowej. Formowanie szlak bojowy internowanie 1920-1924, Toruń 2012.

Za derzhavnist, Varshava 1938, № 8, s. 155-176.

\section{Prasa}

Nove zhyttia, Aleksandriv Kuiavskyi 1921, 6 zhovtnia, № 87, s. 4.

Nove zhyttia, Aleksandriv Kuiavskyi 1921, 14 lystopada, № 94, s. 6.

Propovidnytskyi lystok, Shchypiorno 1923, Sichen, № 2, s. 40.

Relihiino-Naukovyi Visnyk, Aleksandriv Kuiavskyi 1921, 15 veresnia, № 1, s. 28.

Relihiino-Naukovyi Vistnyk, Shchypiorno 1922, Cherven, № 3, s. 38.

Relihiino-Naukovyi Vistny, Shchypiorno 1922, Lystopad, № 4-5, s. 60.

Relihiino-Naukovyi Vistnyk, Shchypiorno 1923, Sichen, № 6, s. 38.

Relihiino-Naukovyi Vistnyk, Shchypiorno 1923, Liutyi-berezen, № 7-8, s. 62.

Relihiino-Naukovyi Vistnyk, Shchypiorno 1923, Kviten-traven, № 9-10, s. 60.

Relihiino-Naukovyi Vistnyk, Shchypiorno 1923, Cherven-lypen, № 11-12, s. 52.

Relihiino-Naukovyi Vistnyk, Shchypiorno 1923, Serpen-zhovten, № 13-15, s. 57.

Soborna Ukraina, Viden 1922, 6 travnia, № 16. 


\title{
SOURCE POTENTIAL OF MATERIALS OF THE ORTHODOX JOURNAL RELIGIOUS-SCIENTIFIC BULLETIN (ALEXANDR KUJAWSKI - SZCZIPIORNO, POLAND) IN 1921-1923
}

\begin{abstract}
Summary
Article analyses the thematic content of world's first Ukrainian-speaking orthodox journal Religious-Scientific Bulletin which was published by Saint Protection Brotherhood of $6^{\text {th }}$ Sich Rifle Division of UPR Army interned initially at the camp Aleksandriv Kuiavskyi, and later at Shchypiorno (1921-1923). The journal illustrated many different materials from religious-philosophic pieces to historical reviews. Bulletin had a regular column "Chronicle" which gave valuable information not only about church life in Ukraine but also in entire Christian realm. Phenomenon of the bulletin lay in the fact that it had a tolerant attitude towards all the religions and beliefs, which wasn't a usual thing for other Christian periodicals. Religious-Scientific Bulletin managed to involve a wide range of teachers, scientists and publicists from different European countries into collaboration thus gaining a worldwide recognition.
\end{abstract}

Keywords: Religious-Scientific Bulletin; camp; orthodox journal; The UPR Army; interned 